\title{
PENGARUH KATALIS NaOH PADA PROSES ISOLASI LIGNIN DARI TANDAN KOSONG KELAPA SAWIT
}

\author{
Masdayani Rambe, Andi Nata, Netti Herlina \\ Departemen Teknik Kimia, Fakultas Teknik, Universitas Sumatera Utara, \\ Jl. Almamater Kampus USU Medan 20155, Indonesia \\ Email: masdayani.rambe@yahoo.co.id
}

\begin{abstract}
Abstrak
Tandan kosong kelapa sawit (TKKS) merupakan salah satu limbah padat yang dihasikan oleh industri perkebunan kelapa sawit yang banyak mengandung serat. Ditinjau dari komposisi kimianya, TKKS mempunyai potensi untuk digunakan sebagai sebagai sumber bahan kimia yaitu lignin. Lignin dapat dimanfaatkan secara komersial sebagai bahan pengikat, perekat, pengisi, surfaktan, produk polimer, dispersan dan sumber bahan kimia lainnya. Penelitian ini menggunakan serbuk serat TKKS yang telah dibersihkan dari zat ekstraktif dengan mengekstraknya menggunakan benzene : etanol $96 \%(2: 1, v / v)$ selama 6 jam. Serbuk serat ini kemudian dimasak dengan variasi pemasakan 1,2,3 jam dengan variasi penambahan $\mathrm{NaOH} \mathrm{10 \% ,15 \% ,dan} \mathrm{20 \%} \mathrm{sehingga} \mathrm{diperoleh} \mathrm{lindi} \mathrm{hitam,} \mathrm{dan}$ variasi pengenceran lindi hitam pada saat isolasi lignin. Hasil penelitian menunjukkan rendemen lignin optimum yang diperoleh yaitu 16,42\% dengan kemurnian lignin 84,21\% pada perlakuan pemasakan 2 jam dengan penambahan $\mathrm{NaOH} 20 \%$ dan proses pengenceran lindi hitam 1:2. Hasil uji FT-IR menunjukkan lignin mempunyai panjang gelombang gugus fungsi penyusun yang sesuai dengan lignin standar.
\end{abstract}

Kata kunci : tandan kosong kelapa sawit,TKKS, lignin, isolasi lignin

\begin{abstract}
Oil palm empty fruit bunches (TKKS) is one of the solid waste generated by the palm oil industry that contain lot of fibers. Based from its chemical composition, TKKS has the potential to be used as a source of chemicals that lignin. Lignin can be used commercially as binders, adhesives, fillers, surfactants, polymer products, dispersants and other chemicals. This study used fiber powder TKKS cleared of extractive substances to extract them using benzene: $96 \%$ ethanol $(2: 1, v / v)$ for 6 hours. Fiber powder is then cooked with a variety of cooking 1,2,3 hours with the addition of $\mathrm{NaOH}$ variation of $10 \%, 15 \%$, and $20 \%$ to obtain the black liquor, black liquor and dilution variations during lignin isolation. The results showed that the optimum yield of lignin obtained is $16.42 \%$ with $84.21 \%$ purity lignin in cooking 2 hour treatment with the addition of $20 \% \mathrm{NaOH}$ and diluting the black liquor 1:2. The test results showed FT-IR has wavelengths lignin constituent functional groups in according with the standard lignin.
\end{abstract}

Keywords: oil palm empty fruit bunches, TKKS, lignin, lignin isolated

\section{Pendahuluan}

Komoditas kelapa sawit memiliki berbagai macam kegunaan baik untuk industri pangan maupun non pangan/oleochemical serta produk samping/limbah. Luas area pertanaman kelapa sawit di Indonesia terus mengalami peningkatan sejak tahun 1999 hingga tahun 2006. Peningkatan tertinggi terjadi dalam kurun waktu 2000 - 2001 yaitu seluas 555,358 Ha (13.36\%) dan kurun waktu 2005 - 2006 yaitu seluas 621,109 Ha (11.39\%).[1]

Saat ini luas area pertanaman kelapa sawit mencapai 7 juta $\mathrm{Ha}$ dan produksi 18 juta ton CPO. Seiring dengan meningkatnya luas area perkebunan kelapa sawit maka limbah tandan kosong kelapa sawit juga semakin meningkat. Maka dari itu perlu dibuat proses isolasi lignin dari tandan kosong kelapa sawit.[1]

\section{Teori}

Lignin merupakan komponen kayu ketiga yang berikatan secara kovalen dengan selulosa dan hemiselulosa. Distribusi lignin di dalam dinding sel dan kandungan lignin bagian pohon yang berbeda tidak sama. Contohnya yaitu kandungan lignin yang tinggi adalah khas untuk bagian batang yang paling rendah, paling tinggi dan paling dalam untuk cabang kayu lunak, kulit, dan kayu tekan.[2]

Umumnya pada penggunaan kayu, lignin digunakan sebagai bagian integral kayu. Dalam pembuatan pulp dan pengelantangan, lignin dilepaskan dari kayu dalam bentuk terdegradasi dan berubah, serta merupakan sumber karbon lebih dari 35 juta ton tiap tahun di seluruh dunia yang sangat potensial untuk keperluan kimia dan energi.[2]

Penggunaan lignin pada saat sekarang dan masa depan merupakan bidang yang luas dan semakin meningkat kepentingannya. Lignin dapat dimanfaatkan sebagai sumber bahan kimia karena lignin mempunyai gugus aktif yang dapat direaksikan dengan gugus lain sehingga menghasilkan senyawa baru dengan struktur dan manfaat berbeda dari struktur kimia senyawa asalnya. Senyawa baru (turunan lignin) diperoleh dengan melakukan modifikasi struktur lignin dengan proses lebih lanjut.[3] 


\section{Metodologi Penelitian}

Proses pulping merupakan proses pelarutan lignin (delignifikasi). Menurut Bahar (1983), selama pemasakan terjadi reaksi cepat dimana terjadi pemutusan ikatan lignin karbohidrat sehingga lignin yang lepas larut dalam larutan pemasak, serta reaksi lambat dimana terjadi kondensasi dan polimerisasi kembali yang menyebabkan lignin tidak larut dalam larutan pemasak. Reaksi kondensasi lignin dapat terjadi dalam proses delignifikasi karena suasana asam akan secara langsung terjadi, yaitu dengan keluarnya gugus asetil dari serpih kayu selama pemasakan. Proses organosolv dapat digambarkan sebagai suatu proses delignifikasi pada suhu pemasakan pulp dengan menggunakan pelarut organik (metanol, etanol, asam asetat, kelompok amina dengan atom $\mathrm{C}$ yang rendah dan lain-lain) sebagai media reaksi. Menurut Bahar (1983), proses organosolv didasarkan pada perbedaan kelarutan komponen kimia bahan baku pulp, dimana lignin dan ekstrakstif larut dalam pelarut organik, karbohidrat dengan bobot molekul rendah dapat larut dalam air sedangkan selulosa tidak larut dalam kedua larutan tersebut. Delignifikasi pada proses organosolv disebabkan oleh terputusnya ikatan eter dalam molekul lignin.[5]

\section{Hasil dan Pembahasan}

Pada penelitian ini, dalam rangka pencirian gugus fungsi polimer isolat lignin dari tandan kosong kelapa sawit (TKKS) dilakukan dengan cara sidik jari (fingerprinting) dengan piranti inframerah (IR), yaitu menggunakan Fourier Transform InfraRed Spectroscopy (FT-IR). Isolat lignin yang dihasilkan dari kondisi isolasi terbaik dan menghasilkan rendemen dan kemurnian terbesar, selanjutnya diidentifikasi lebih lanjut dengan spektrofotometer FT-IR.[4]

Menurut Nuryanto

(2000) spektrofotometerskopi inframerah merupakan salah satu teknik identifikasi struktur baik untuk senyawa organik maupun senyawa anorganik. Analisa ini merupakan metode semi empirik dimana kombinasi pita serapan yang khas dapat diperoleh untuk menentukan struktur senyawa yang terdapat pada suatu bahan.[4]

Isolat lignin yang diuji merupakan isolat lignin hasil penelitian dengan kombinasi perlakuan terbaik yang diperoleh yaitu kombinasi perlakuan pemasakan lindi hitam selama 2 jam, dengan penambahan katalis $\mathrm{NaOH}$ $20 \%$, dan proses perbandingan pengenceran lindi hitam 1:1.[4]

Salah satu cara analisa untuk mengetahui keberhasilan isolasi lignin adalah dengan mengidentifikasi gugus fungsi yang ada. Analisa ini dilakukan dengan alat FT-IR yang mampu mengidentifikasi serapan-serapan khas untuk masing-masing gugus fungsi yang terkandung dalam sampel. Lignin merupakan polimer dari gugus hidroksil fenolik, hidroksil benzilik dan gugus karbonil. Polimer lignin mengandung gugus-gugus Secara umum lignin tersusun atas unit guaiasil, siringil, parahidroksil propana, $-\mathrm{OH}$, dan beberapa gugus aldehida ujung dalam rantai samping.[6]

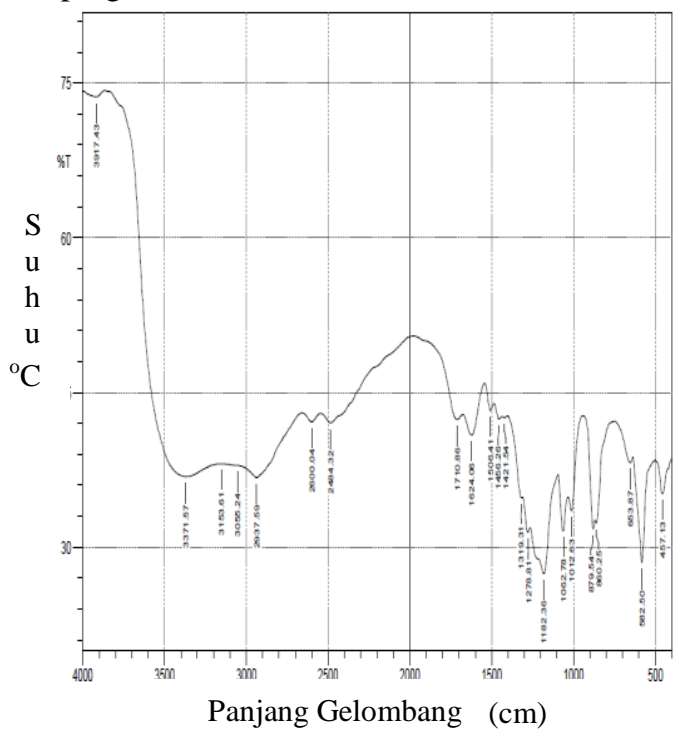

Gambar 1. FT-IR LIGNIN ISOLAT

Pada Gambar I, hasil identifikasi gugus fungsi dengan FT-IR lignin kraft menunjukkan pola serapan pada daerah bilangan gelombang yang menunjukkan kisaran standar pita serapan pada lignin dan yang diperoleh pada penelitian. Pita serapan pada bilangan gelombang 3414,00 $\mathrm{cm}^{-1}$ menunjukkan uluran O-H. Pada pita serapan pada bilangan 2939,52 $\mathrm{cm}^{-1}$ diperoleh pada penelitian ini, menunjukkan uluran $\mathrm{C}-\mathrm{H}$ metil. Dua pita serapan pada bilangan gelombang $1633,71 \mathrm{~cm}^{-1}$ dan $1506,41 \mathrm{~cm}^{-1}$ pada lignin yang diperoleh merupakan karakteristik dari cincin aromatic. Selanjutnya untuk pita serapan pada bilangan 1468,18 $\mathrm{cm}^{-1}$ menunjukkan gugus $\mathrm{C}-\mathrm{H}$ asimetris. Untuk pita serapan pada bilangan $1278,81 \mathrm{~cm}^{-1}$ menunjukan vibrasi cincin guasil, serapan pita pada bilangan 1060,85 $\mathrm{cm}^{-1}$ menunjukkan uluran eter dan serapan pada bilangan $862,18 \mathrm{~cm}^{-1}$.[6]

Berdasarkan gambar grafik FT-IR pada rentang bilangan gelombang antara 400-4000 $\mathrm{cm}^{-1}$ di atas dapat dilihat bahwa telah sesuai dengan standar kisaran pita serapan pada lignin dan relevan dengan gugus umum yang terdapat dalam lignin. Sehingga dapat disimpulkan bahwa senyawa tersebut memang benar-benar lignin.[6] 
Adapun beberapa peak atau puncak absorbansi yang terjadi selain gugus umum tersebut disebabkan beberapa hal seperti sumber lignin yang berbeda, kemurnian lignin yang tidak terlalu sempurna yang menyebabkan adanya beberapa gugus pengotor yang masih terkadung dalam isolat lignin, terdapat variasi yang besar dalam struktur dan komposisi lignin, dan teknik pengukuran lignin yang berbeda dalam pelarut yang sesuai.[6]

\section{Kesimpulan}

Tandan kosong kelapa sawit (TKKS) merupakan salah satu alternatif sumber lignin yang layak digunakan karena telah dibuktikan/diuji dengan FT-IR dan menambah nilai ekonomis TKKS tersebut. Waktu pemasakan dan konsentrasi katalis $\mathrm{NaOH}$ berpengaruh terhadap proses isolasi lignin, sedangkan pengenceran lindi hitam pengaruhnya sangat kecil sekali. Adapun keadaan optimum untuk rendemen lignin tertinggi yaitu $16,42 \%$ pada perlakuan pemasakan 2 jam dengan penambahan katalis $\mathrm{NaOH} 20 \%$ dan proses pengenceran lindi hitam 1:2. Adapun keadaan optimum untuk kemurnian lignin tertinggi yaitu $87,63 \%$ dengan perlakuan pemasakan 2 jam dengan penambahan katalis $\mathrm{NaOH} 20 \%$ dan proses pengenceran lindi hitam 1:1. Berdasarkan uji FT-IR terdeteksinya gugus unit guaiasil, siringil, parahidroksil propana, $-\mathrm{OH}$ yaitu senyawa gugus penyusun lignin.

\section{Daftar Pustaka}

[1] Dirattanhun, 2008, Pemanfaatan Limbah dan Hasil Samping Kelapa Sawit. Pada http:// ditjenbun.go.id/. 13 April 2009.

[2] Fengel, D. dan G. Wegener,Kayu : Kimia, Ultrastruktur,Reaksi-Reaksi. Diterjemaahkan oleh Sastrohamidjojo, H. Terjemahan dari : Wood : Chemical, Ultrastructure, Reactions. Gadjah Mada University Press, Yogyakarta,1995.

[3] Naibaho, P.M. Diversifikasi Minyak Kelapa Sawit dan Inti Sawit dalam Upaya Meningkatkan daya Saing dengan Minyak Nabati lainnya dan Hewani. Buletin erkebunan, 21(2) : 107-124,1990.

[4] Nuryanto, eka(2000), Isolasi dan Degradasi Lignin Dari Lindi Hitam Pulp Tandan Kosong Sawit secara kimia. tesis magister kimia, ITB Press, Bandung, 2000.

[5] Rostika, I. M. Eddy, T. Bastian, E. Yuliani dan D. Elut, Upaya Peningkatan Kualitas Pulp Organosolv. Prosiding pada Simposium Selulosa dan Kertas XIV, 12-13 Januari, 1994.

[6] Sarkanen, K. V. S. Assiz and V. Chiang, Organosolv Pulping. Semi mannual Report I and II, College of Forest Resources, Univ. of Washington, New York, 1980. 